\title{
Incidence of Maize Stem Borer, Chilo partellus (Swinhoe) in Relation to
} Abiotic Factors on Maize

\author{
Insha Hamid $^{1 *}$, R.K. Nehru ${ }^{1}$, A.R. Wani ${ }^{1}$, S.S. Pathania ${ }^{1}$, \\ Qurat Ul Ain ${ }^{1}$ and Furqan Hamid ${ }^{2}$ \\ ${ }^{1}$ Division of Entomology, ${ }^{2}$ Division of Economics, Sher-e-Kashmir University of Agricultural \\ Science \& Technology, Kashmir, (J. \& K.), India \\ *Corresponding author
}

\begin{abstract}
A B S T R A C T
\section{Keywords}

Maize Stem Borer,

Chilo partellus,

Abiotic factors on maize

Article Info

Accepted:

07 May 2019

Available Online:

10 June 2019

Studies were conducted on the incidence of maize stem borer, Chilo partellus (Swinhoe) at DARS, Budgam, SKUAST-K during the Kharif season, 2015. The incidence of the insect was assessed in maize variety C-15 sown in April 2015. The lowest leaf infestation recorded during entire crop season was first observed in $18^{\text {th }}$ standard week $(\mathrm{SW})\left(1^{\text {st }}\right.$ week of May) with leaf infestation of 4.00 per cent while the highest infestation was recorded in $28^{\text {th }} \mathrm{SW}$ ( $2^{\text {nd }}$ week of July) as 48.50 per cent. The lowest dead heart occurrence of 6.50 per cent was recorded in $20^{\text {th }} \mathrm{SW}$ ( $3^{\text {rd }}$ week of May) and the highest was 37.00 per cent in $27^{\text {th }}$ SW ( $1^{\text {st }}$ week of July). Similarly the adult moth catch was found lowest in $17^{\text {th }} \mathrm{SW}$ ( $4^{\text {th }}$ week of April) with 5.00 moths/trap and highest in $24^{\text {th }} \mathrm{SW}$ ( $2^{\text {nd }}$ week of June) with 20.00 moths/trap. A positive and significant correlation was found between leaf infestation, dead heart and moth catch with maximum temperature, minimum temperature, maximum relative humidity, however, correlation was positive but non-significant with rainfall while a negative and non-significant correlation with sunshine and minimum relative humidity was observed. The adult moth catch was found to be non-significant but positively correlated with minimum relative humidity.
\end{abstract}

\section{Introduction}

Maize (Zea mays Linn.) is one of the important cereal crops next to wheat and rice in terms of total production in the world, ranks third in area and first in production in the world. In India, maize is cultivated on an area of about 8.3 million hectares with a production of 21 million tonnes with average yield of 2.5 tonnes per hectare (Anonymous, 2011). In the state of Jammu and Kashmir, it is cultivated over an area of about 0.32 million hectares with a production and productivity level of 0.55 million tonnes and 1.75 tonnes per hectare, respectively (Anonymous 2012). Productivity of maize in Kashmir valley under rainfed conditions is 11.5 quintals per hectare as against 23.0 quintals per hectare in sub-tropics of Jammu (Anonymous, 2013). It is considered as highest yielding cereal crop in the world and is of significant importance for countries like 
India where rapidly increasing population has already out stripped the available food supplies (Mghenyi, 2006). Maize crop is attacked by a number of insect pests. Among these maize stem borer (Chilo partellus Swinhoe), is of greater importance. It is key crop destroyer and the pest has been reported to cause severe losses in maize crop throughout its geographical distribution and the yield losses of 75 per cent have been documented by the borer alone besides, crop may even fail if it remains uncontrolled (Latif et al., 1960). The larvae of $C$. partellus after hatching feed on soft surface of the leaves and then enter the stem through whorl for feeding on the pith of the stem. The growth of the plants becomes stunted and resulting in dead hearts when attacked by $C$. partellus at their initial stages. The larvae migrate from other plants and enter the stem through lower nodes by making the holes (Lella and Srivastav (2013). Despite of, extensive work carried in India and abroad on the $C$. partellus, a thorough investigation in Kashmir division is lacking. Keeping in view the economic importance of the pest, it is imperative to study the incidence of the pest.

\section{Materials and Methods}

The present study was conducted at Experimental Field of Dryland (Karewa) Agricultural Research Station (DARS), Budgam- a constituent of SKUAST- Kashmir, Shalimar. To ascertain the incidence of $C$. partellus, the sowing of the maize variety $\mathrm{C}$ 15 was carried in the plots of $3 \square 2 \mathrm{~m}$ on 13 April, 2015 by maintaining row to row and plant to plant spacing of 60 and $20 \mathrm{~cm}$, respectively. All agronomical package of practices recommended by SKUASTKashmir (Anonymous, 2011) for successful cultivation of crop was followed. After 12 days of germination, 10 plants from five plots were randomly selected and tagged. Observations regarding the pest incidence were carried out throughout the entire cropping season at weekly intervals starting from last week of April (17SW) by recording leaf infestation, dead heart and adult moth catch.

\section{Per cent leaf infestation}

Pin hole and window injury caused by newly hatched larvae of $C$. partellus were recorded at weekly intervals.

The per cent leaf infestation was calculated by using the formulae:

Per cent infestation $=\frac{\begin{array}{c}\text { No. of infested } \\ \text { leaves }\end{array}}{\begin{array}{c}\text { Total No. of } \\ \text { leaves }\end{array}} \times 100$

\section{Per cent dead heart}

Dead heart formation by $C$. partellus was recorded at weekly intervals using the below mentioned formulae:

$\begin{aligned} & \text { Per cent dead } \\ & \text { heart }=\end{aligned} \frac{\begin{array}{c}\text { No. of dead } \\ \text { hearts }\end{array}}{\begin{array}{c}\text { Total No. of } \\ \text { plants }\end{array}} \times 100$

Adult population of $C$. partellus was monitored at weekly intervals by using light traps and continued till the crop attained senescence. Weekly meteorological data on temperature, relative humidity, rainfall and sunshine, throughout the experimental period 2015 was procured from the DARS, Budgam. The simple correlation studies between leaf infestation, dead heart and adult moth catch with all abiotic factors were worked out so as to determine their impact on pest incidence on maize crop. The research data was analyzed using R-Software to obtain correlation between leaf infestation, dead heart and adult moth catch with various abiotic factors. 


\section{Results and Discussion}

Studies conducted to ascertain the extent of leaf damage at DARS, Budgam during Kharif, 2015 revealed that the leaf infestation by $C$. partellus was first observed during $18^{\text {th }}$ SW with initial infestation of 4.00 per cent corresponding to weather factors of $23.78^{\circ} \mathrm{C}$ $(\operatorname{Max} \mathrm{T}), 10.30^{\circ} \mathrm{C}(\operatorname{Min} \mathrm{T}), 76.42$ per cent (Max RH), 64.14 per cent (Min RH), 2.65 $\mathrm{mm}$ (TRF) and $5.35 \mathrm{~h}$ (SSH). Thereafter, infestation gradually increased and peaked to
48.50 per cent at $28^{\text {th }} \mathrm{SW}$ when Max T was $31.35^{\circ} \mathrm{C}$, Min $\mathrm{T} \quad\left(18.01^{\circ} \mathrm{C}\right), \quad \operatorname{Max} \mathrm{RH}$ (87.14\%), Min RH (61.30\%), TRF (1.45 $\mathrm{mm})$, SSH (12.27 h) (Table 1). The present findings are more or less supported by the work of Dharmasena (2002). The dead heart symptom by $C$. partellus was first recorded at $20^{\text {th }} \mathrm{SW}$ with initial damage of 6.50 per cent corresponding to weather factors of $22.85^{\circ} \mathrm{C}$ $(\operatorname{Max} \mathrm{T}), 7.92^{\circ} \mathrm{C}(\operatorname{Min} \mathrm{T}), 77.00$ per cent (Max RH), 66.71 per cent (Min RH), 2.45 $\mathrm{mm}$ (TRF) and $5.90 \mathrm{~h}$ (SSH) (Fig. 1-3).

Table.1 Influence of abiotic factors on maize stem borer, Chilo partellus (Swinhoe) at Dryland (Karewa) Agriculture Research Station, Budgam during Kharif, 2015

\begin{tabular}{|c|c|c|c|c|c|c|c|c|c|}
\hline \multirow[t]{2}{*}{$\begin{array}{c}\text { Standard } \\
\text { week }\end{array}$} & \multirow{2}{*}{$\begin{array}{c}\text { Per cent } \\
\text { leaf } \\
\text { infestation }\end{array}$} & \multirow{2}{*}{$\begin{array}{l}\text { Per } \\
\text { cent } \\
\text { dead } \\
\text { heart }\end{array}$} & \multirow{2}{*}{$\begin{array}{l}\text { Adult } \\
\text { moth } \\
\text { catch }\end{array}$} & \multicolumn{2}{|c|}{$\begin{array}{c}\text { Temperature } \\
\left({ }^{\circ} \mathrm{C}\right)\end{array}$} & \multicolumn{2}{|c|}{$\begin{array}{c}\text { Relative } \\
\text { humidity (\%) }\end{array}$} & \multirow{2}{*}{$\begin{array}{c}\text { Total } \\
\text { rainfall } \\
(\mathbf{m m})\end{array}$} & \multirow[t]{2}{*}{$\begin{array}{c}\text { Sunshine } \\
\text { (hrs) }\end{array}$} \\
\hline & & & & Max. & Min. & Max. & Min. & & \\
\hline 17 & - & - & 5.00 & 23.25 & 6.55 & 69.00 & 46.00 & 0.00 & 9.12 \\
\hline 18 & 4.00 & 0.00 & 6.50 & 23.78 & 10.30 & 76.42 & 64.14 & 2.65 & 5.35 \\
\hline 19 & 8.20 & 0.00 & 7.00 & 23.78 & 10.35 & 87.71 & 61.42 & 3.88 & 4.88 \\
\hline 20 & 12.80 & 6.50 & 7.00 & 22.85 & 7.92 & 77.00 & 66.71 & 2.45 & 5.90 \\
\hline 21 & 17.60 & 14.55 & 9.50 & 22.14 & 9.60 & 76.00 & 60.85 & 1.17 & 5.92 \\
\hline 22 & 23.20 & 20.12 & 14.00 & 22.92 & 11.64 & 83.28 & 67.85 & 4.60 & 5.97 \\
\hline 23 & 29.20 & 24.92 & 18.00 & 27.50 & 13.50 & 73.85 & 51.28 & 1.20 & 8.15 \\
\hline 24 & 36.10 & 29.00 & 20.00 & 30.57 & 14.30 & 71.42 & 54.40 & 1.34 & 8.98 \\
\hline 25 & 41.50 & 32.73 & 16.00 & 26.00 & 11.00 & 77.85 & 56.71 & 9.80 & 6.42 \\
\hline 26 & 44.70 & 35.40 & 12.00 & 28.85 & 17.34 & 74.14 & 53.57 & 1.51 & 10.14 \\
\hline 27 & 47.60 & 37.00 & 8.50 & 25.57 & 17.45 & 88.57 & 70.42 & 9.41 & 2.50 \\
\hline 28 & 48.50 & 37.00 & 6.00 & 31.35 & 18.01 & 87.14 & 61.30 & 1.45 & 12.27 \\
\hline 29 & 48.50 & 37.00 & 5.50 & 29.64 & 17.71 & 84.00 & 61.42 & 6.11 & 8.22 \\
\hline 30 & 48.50 & 37.00 & 5.00 & 29.50 & 18.81 & 89.14 & 60.28 & 21.14 & 5.14 \\
\hline 31 & 48.50 & 37.00 & 4.00 & 31.30 & 18.42 & 83.00 & 57.28 & 0.00 & 7.58 \\
\hline 32 & 48.50 & 37.00 & 4.00 & 29.71 & 15.84 & 78.28 & 56.28 & 0.54 & 7.82 \\
\hline 33 & 48.50 & 37.00 & 3.00 & 29.78 & 14.89 & 81.85 & 47.85 & 11.28 & 8.14 \\
\hline 34 & 48.50 & 37.00 & 2.00 & 29.14 & 12.50 & 81.00 & 48.85 & 0.00 & 8.00 \\
\hline 35 & 48.50 & 37.00 & 1.00 & 25.71 & 11.22 & 87.00 & 53.85 & 1.94 & 7.01 \\
\hline 36 & 48.50 & 37.00 & 0.00 & 29.42 & 9.90 & 82.71 & 46.71 & 0.00 & 9.27 \\
\hline 37 & 48.50 & 37.00 & 0.00 & 24.92 & 10.14 & 81.85 & 57.57 & 8.28 & 6.12 \\
\hline
\end{tabular}


Table.2 Correlation coefficient of leaf infestation, dead heart and adult moth catch of Chilo partellus (Swinhoe) with abiotic factors during Kharif, 2015

\begin{tabular}{|c|c|c|c|}
\hline Abiotic factors & $\begin{array}{l}\text { Per cent leaf } \\
\text { infestation }\end{array}$ & $\begin{array}{l}\text { Per cent dead } \\
\text { heart }\end{array}$ & $\begin{array}{l}\text { Adult moth } \\
\text { catch }\end{array}$ \\
\hline Temperature (Max.) $\left({ }^{\circ} \mathrm{C}\right)$ & $0.749 * *$ & $0.762 * *$ & $0.831 * *$ \\
\hline Temperature (Min.) $\left({ }^{\circ} \mathrm{C}\right)$ & $0.687 * *$ & $0.675 * *$ & $0.913 * *$ \\
\hline Per cent Relative Humidity (Max.) & $0.472 *$ & $0.416^{*}$ & $0.472 *$ \\
\hline Per cent Relative Humidity (Min.) & -0.085 & 0.155 & -0.134 \\
\hline Rainfall (mm) & 0.323 & 0.317 & 0.470 \\
\hline Sunshine (hrs) & -0.168 & -0.187 & -0.229 \\
\hline
\end{tabular}

Fig.1 Leaf infestation by maize stem borer, C. partellus (Swinhoe) corresponding to abiotic factors

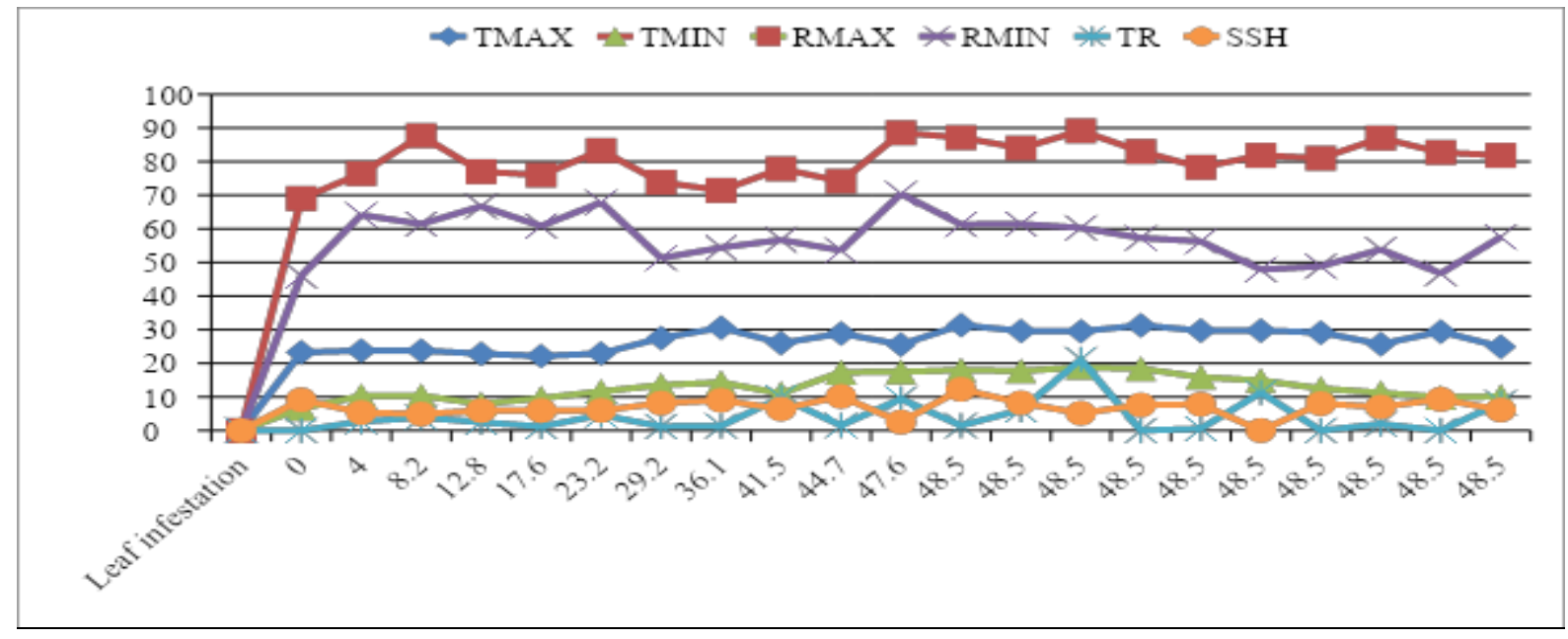

Fig.2 Dead heart by maize stem borer, C. partellus (Swinhoe) corresponding to abiotic factors

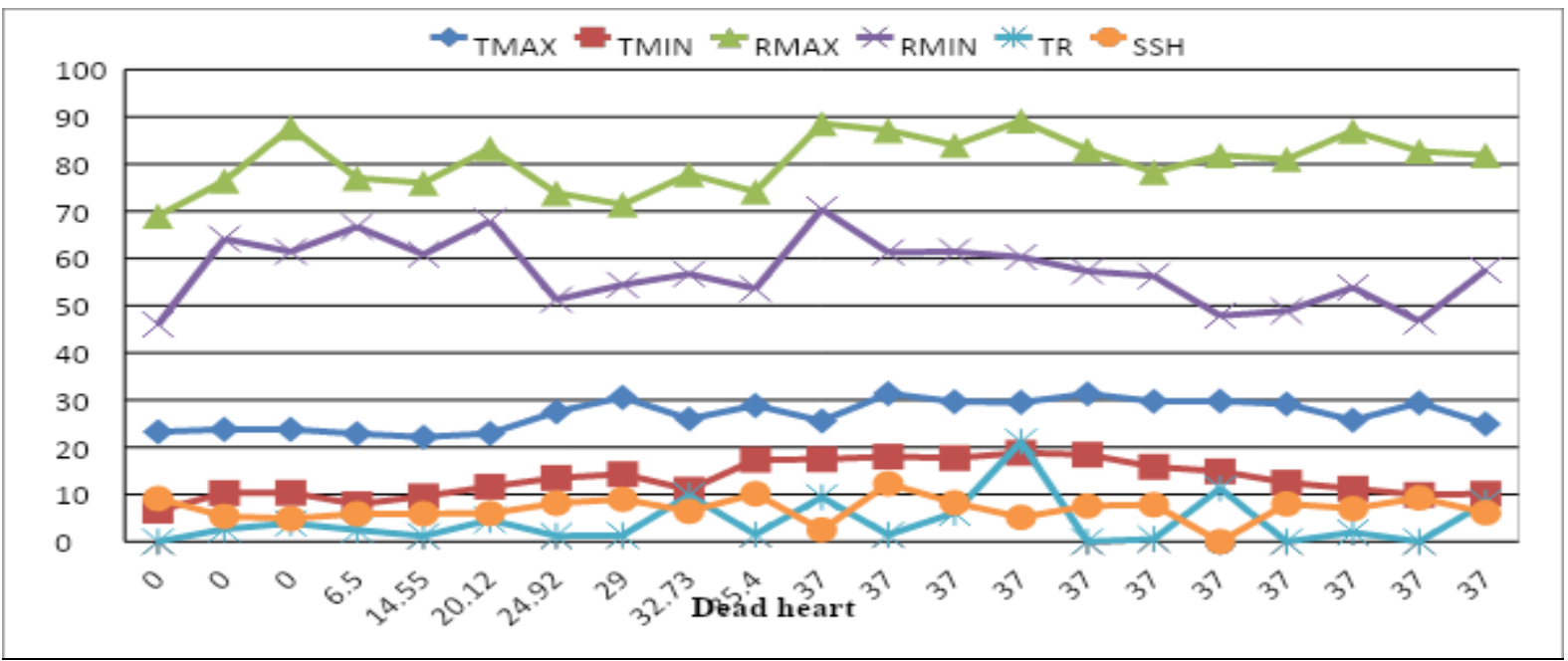


Fig.3 Adult moth catch of maize stem borer, C. partellus (Swinhoe) corresponding to abiotic factors

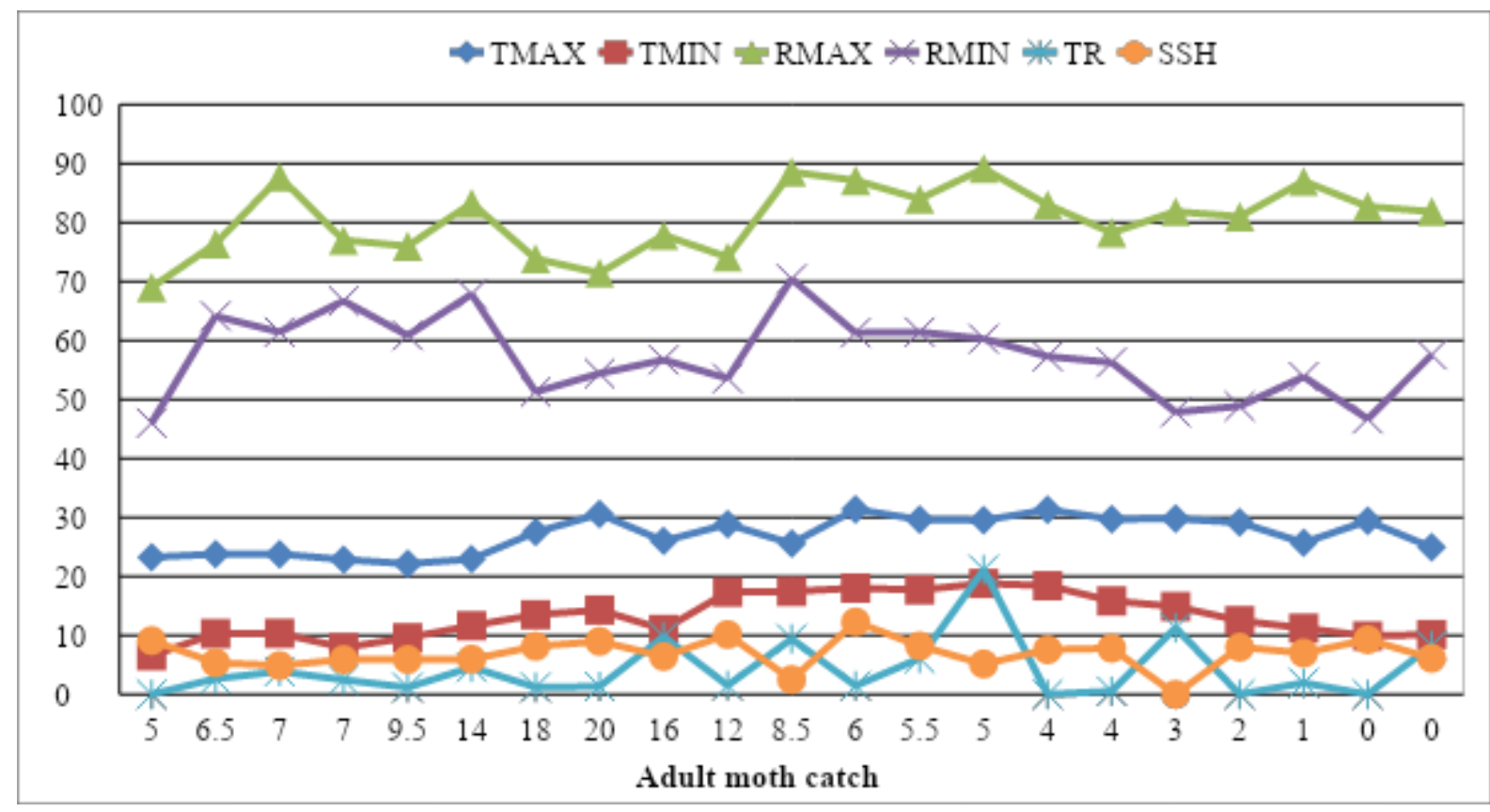

The dead heart gradually increased and peaked at 37.00 per cent $\left(27^{\text {th }} \mathrm{SW}\right)$ at $25.57^{\circ} \mathrm{C}$ $(\operatorname{Max} \mathrm{T}), 17.45^{\circ} \mathrm{C}(\operatorname{Min} \mathrm{T}), 88.57$ per cent (Max RH), 70.42 per cent (Min RH), 9.41 $\mathrm{mm}$ (TRF) and $2.50 \mathrm{~h}$ (SSH) (Table 1). The maximum dead heart of 37.00 per cent was recorded at temperature of $31.35^{\circ} \mathrm{C}$ per cent obtained during the present findings are more or less supported by Muhammad et al., (2010) who reported maximum plant damage (dead heart) of $C$. partellus at maximum temperature of $32.5^{\circ} \mathrm{C}$. Furthermore, Thakur et al., (2013) too recorded highest plant damage (dead heart) at maximum temperature of $32.05^{\circ} \mathrm{C}$. The adult moth catch of maize stem borer was first trapped during $17^{\text {th }} \mathrm{SW}$ with mean moth catch of 5.00 adults/trap at maximum temperature of $23.25^{\circ} \mathrm{C}$, Min $\mathrm{T}$ $\left(6.55^{\circ} \mathrm{C}\right)$, Max RH (69.0\%), Min RH (46.0\%), TRF $(0.0 \mathrm{~mm})$ and SSH $(9.12 \mathrm{~h})$. The moth catch gradually increased to the highest peak of 20.00 moths/trap during $24^{\text {th }} \mathrm{SW}$ at $30.57^{\circ} \mathrm{C}$ (Max T), $14.30^{\circ} \mathrm{C}$ (Min $\left.\mathrm{T}\right), 71.42$ per cent (Max RH), 54.40 per cent (Min RH), $1.34 \mathrm{~mm}$ (TRF) and $8.98 \mathrm{~h}(\mathrm{SSH})$ (Table 1).
The present findings are in close proximity with the work of Ahad et al., (2008).

Perusal of Table 2 indicated that in the present investigation, the simple correlation studies between various abiotic factors with leaf infestation, dead heart, adult moth catch of $C$. partellus revealed positive and significant correlation with maximum temperature, minimum temperature and maximum relative humidity, but, rainfall had positive and non-significant correlation; the sunshine and minimum relative humidity had negative and non-significant correlation; though, adult moth catch had positive and non-significant correlation with minimum relative humidity. The present study is in conformity with the work of Meti et al., (2014) and Ahad et al., (2008).

\section{References}

Ahad, I., Bhagat, R. M., Ahmad, H. and Monobrullah, M. 2008. Population dynamics of maize stem borer, Chilo 
partellus (Swinhoe) in upper Himalayas of Jammu region. Journal of BioScience 16: 137-138.

Anonymous, 2011. Cereal Crops (Kharif and Rabi) Package of Practices 3: 19-34.

Anonymous, 2011. Food and Agriculture Organisation of the United Nations. FAOSTAT database. http://www.fao. org.

Anonymous, 2012. Agricultural Statistics, Directorate of Economics and Statistics. Department of Economics and Statistics. Department of Agriculture and Cooperation, Ministry of Agriculture, Government of India.

Anonymous, 2013. Annual Report on Impact Assessment of Frontline Demonstration in Maize, pp. 1-2. Dryland (Karewa) Agriculture Research Station SKUASTKashmir, Budgam.

Dharmasena, C. M. D. 2002. Temporal distribution of maize stem borer Chilo partellus (Swinhoe) in relation to weather factors. Tropical Agriculture 151: 1-6.

Latif, A., Cayyum, A. and Piracha, M. A. 1960. Maize Stem Borer Chilo partellus (Swinhoe) and its control. Agriculture in Pakistan 11: 25-36.

Lella, R. and Srivastav, C. P. 2013. Screening of maize genotypes against stem borer,
Chilo partellus L. in kharif season. International Journal of Applied Biology and Pharmaceutical Technology 4(4): 394-403.

Meti, P., Sreenivas, A. G., Prakash, K., Jat, M. L. V., Prabhuraj, N. M. and Singh, Y. K. 2014. Population dynamics of shoot fly and stem borer of maize under conservation agriculture system. Journal of Experimental Zoology 17(2): 563-566.

Mghenyi, W. E. 2006. Welfare effects of maize pricing policy on rural households in Kenya, Department of Agricultural Economics, Michigan State University, USA. Unpublished Master's Thesis.

Muhammad, A. Z., Muhammad, A. S., Muhammmad, A. R., Amir, H., Asim, H. and Ahsan, K. 2010. Effect of temperature and relative humidity on the population dynamics of some insect pests of maize. Pakistan Journal of Life Social Sciences 8(1): 16-18.

Thakur, P., Shrestha, J., Bhandari, G. S. and Achhemin, B. B. 2013. Insect scenario and its succession in year round weekly interval seeded maize varieties at Rampur, Chitwan, Nepal. International Journal of Modern Plant and Animal Sciences 1(2): 96-104.

\section{How to cite this article:}

Insha Hamid, R.K. Nehru, A.R. Wani, S.S. Pathania, Qurat Ul Ain and Furqan Hamid. 2019. Incidence of Maize Stem Borer, Chilo partellus (Swinhoe) in Relation to Abiotic Factors on Maize. Int.J.Curr.Microbiol.App.Sci. 8(06): 678-683. doi: https://doi.org/10.20546/ijcmas.2019.806.078 